\title{
Economic Analysis of Natural Gas Reserves Addition from Coal Bed Methane in Nigeria
}

\author{
Green A. Ibim, Ugoji U. Kelechi, and Igbere B. Ndukam
}

\begin{abstract}
The aim of this project is to economically analyze Coal Bed Methane (CBM) development in Nigeria. This will offer an opportunity to use gas from the Nation huge coal reserves for domestic and exportation purposes to boost the economy of Nigeria. CBM can be used to generate power as well as manufacture alternative products. The profitability of coal bed methane (CBM) project depends on factors such as seam thickness, gas content, methane content, coal rank and permeability. Its economics are influenced by other variables, such as fiscal policy, depth of coal seam, volume of water disposal, access to market and price of gas. Potential and existing sites for coal bed methane extraction in Nigeria were identified. Kim's equation was used to estimate the gas content. The gas-in-place was derived with Volumetric method. Methane quantification was estimated using Eddy curve. It is observed that the ultimate reserves, the capital costs, and the gas price have significant effect on the net present value (NPV) and internal rate of returns (IRR) and thus the economic viability of the project. Economic analysis of LNG and Pipeline projects for gas transmission were comparatively examined. It is observed that the gas price and demand at the market hub depend largely on the mode of transmission.
\end{abstract}

Index Terms-Coal Bed Methane; Kim's Equation; Net Present Value; Volume.

\section{INTRODUCTION}

When organic material is geologically turned into coal, Methane gas is produced. Coal Bed Methane (CBM) is a water saturated coal, such that methane is trapped within the coal in the conversion process.

Nigeria has major unexploited coal resources. The federal government has recently reiterated its commitment to boost the energy sector by utilizing the abundant coal reserve in the country [4].

According to the Nigerian Coal Corporation [12], the Anambra basin located in the south eastern Nigeria appears to contain the largest and most viable coal resources. The basin is constrained by the Niger River on the west, the Benue River on the north and the Enugu Escarpment on the East. The basin covers an area of approximately 1.5 million hectares and comprises of eight Coal fields, namely: Oba Nnewi, Ezimo, Ogboyoga, Okaba, Orukpa, Onyeama, Okpara and Inyi Coal Seam Gas [12].

Published on April 8, 2019.

I. A. Green is presently with the Department of Mechanical Engineering Technology, Federal Polytechnic of Oil and Gas Bonny. Rivers State. Nigeria. (abba.green@yahoo.com).

U. K. Ugoji is presently with the Department of Mechanical Engineering Technology, Federal Polytechnic of Oil and Gas Bonny. Rivers State. Nigeria.

B. N. Igbere is presently with the Department of Mechanical Engineering Technology, Federal Polytechnic of Oil and Gas Bonny. Rivers State, Nigeria

\section{LITERATURE REVIEW}

There are existing literatures related to the operational parameters and economics of coal-bed methane production. The key data required for analysis of coal bed methane reservoirs are gas resources, reserves and deliverability [7]. Gas in place in a CBM reservoir can be estimated using the parameters such as average in-situ gas content, coal thickness, reservoir or well drainage area and average in-situ coal density [9]. They stated that gas reserves can be calculated by multiplying gas-in-place by the estimated recovery factor at the economic limit. The flow of fluids (gas and water) to the wellbore (deliverability) in CBM reservoirs takes place through the natural fracture system (cleats) [3]. They concluded that the properties of the natural fracture system have the greatest effect on gas and water production rates and that an accurate estimate of deliverability requires accurate estimates of the coal natural fracture system flow properties. As shown in [1], only certain ranks of coal are suitable for CBM production. As temperature and pressure increase, the rank of the coal changes along with its ability to generate and store methane. Each type adsorbs different volumes of methane and the ability for coal to store methane increases with rank. According to [6], coal bed methane production requires lowpressure pipeline systems and facilities for water disposal and the lack of an existing infrastructure (from a conventional natural gas play) can make initial costs high. Higher gas prices or tax credits may be needed to make development economic.

\section{DERIVATION OF COAL DATA IN Nigeria}

The analysis assumed a well spacing of 100arces and recovery factor of $50 \%$ for each coal field. The study employed Kim's equation to estimate the average gas content as:

$$
\mathrm{V}=(100-\mathrm{M}-\mathrm{A}) / 100 \mathrm{x}[\mathrm{Vw} / \mathrm{Vv}]\left[\mathrm{KP}^{\mathrm{N}}-\mathrm{bT}\right]
$$

Where; $\mathrm{V}$ is the methane gas adsorbed, $\mathrm{M}$ is the moisture content, $\mathrm{A}$ is the Ash content, $\mathrm{V}_{\mathrm{w}}$ is Volume of gas adsorbed on wet coal, $V_{d}$ is Volume of gas adsorbed on dry coal, $b$ is the adsorption constant due to temperature change, $\mathrm{T}$ is the temperature at given depth, $\mathrm{K}$ and $\mathrm{N}$ depends on the rank of coal and is express as ratio of fixed carbon to volatile matter.

Volumetric method was used to estimate the Gas in place. Eddy curve was used to quantify the methane gas contained in each Coal seam. 


$$
\mathrm{G}=(\mathrm{Ah} \Phi \mathrm{Sgi}) / \mathrm{Bgi}
$$

Where; $G$ is the Gas in place, $A$ is the Area, $S_{\text {gi }}$ is Gas saturation, $B_{g i}$ is the Gas formation volume factor and $\Phi$ is Porosity.

\section{A. Oba Nnewi Basin}

Let the well spacing be 100acres. Applying Kim's equation: $\quad \mathrm{GC}_{\text {average }}=332.14$ scf/ton. Using volumetric method to calculate the Gas in place,

$$
\frac{\text { tonnage }}{\text { volume }}=4,839 \frac{\text { tonnage }}{\text { acre }-f t}
$$

Gas in place $=1,054,613,130$ scfUsing a $50 \%$ recovery factor and 2 drilled holes, Reserve gas $=1,054,613,130$ scf.

The maximum methane resources per ton of in situ coal contained in the Oba Nnewi basin is estimated to be 309cf/ton using Empirical curve introduced by Eddy.

\section{B. Ogboyoga Basin}

Applying Kim's equation: $\mathrm{GC}_{\text {average }}=332.14$ scf/ton Using volumetric method to calculate the Gas in place,

$$
\frac{\text { tonnage }}{\text { volume }}=9,900.25 \frac{\text { tonnage }}{\text { acre }-f t}
$$

Gas in place $=2,157,663,490$ scf. Using a $50 \%$ recovery factor and 27 drilled holes; Reserve gas = $29,128,457,300$ scf. From Eddy curve, Methane resources = $310 \mathrm{cf} /$ ton

\section{Okaba Basin}

Applying Kim's equation: GC $_{\text {average }}=332.14 \mathrm{scf} / \mathrm{ton}$. Using volumetric method to calculate the Gas in place, Gas in place $=9,546,997,390 \mathrm{scf}$. Using 50\% recovery factor and 17 core holes drilled, Reserve gas $=81,149,477,900 \mathrm{scf}$. From Eddy curve, Methane resources $=327 \mathrm{cf} /$ ton.

\section{Orukpa Basin}

Applying Kim's equation: $\mathrm{GC}_{\text {average }}=332.14 \mathrm{scf} / \mathrm{ton}$. Using volumetric method to calculate the Gas in place, Gas in place $=1,853,214,000$ scf. Using $50 \%$ recovery factor and 11 holes drilled, Reserve gas $=10,192,677.000$ scf. From Eddy curve, Methane resources $=327 \mathrm{cf} / \mathrm{ton}$.

\section{E. Ezimo Basin}

Applying Kim's equation: $\mathrm{GC}_{\text {average }}=332.14 \mathrm{scf} /$ ton. Using volumetric method to calculate the Gas in place, Gas in place $=983,864,271 \mathrm{scf}$. Using 50\% recovery factor and 4 core holes drilled, Reserve gas $=1,967,728,400$ scf. From Eddy curve, Methane resources $=308 \mathrm{cf} /$ ton.

\section{F. Orukpa Basin}

Applying Kim's equation: $\mathrm{GC}_{\text {average }}=332.14 \mathrm{scf} /$ ton . Using volumetric method to calculate the Gas in place, Gas in place $=4,069,529,970 \mathrm{scf}$ Using $50 \%$ recovery factor and 36 core holes drilled, Reserve gas $=73,251,539,600$ scf. From Eddy curve, Methane resources $=329 \mathrm{cf} /$ ton.

\section{G. Inyi Graben}

Applying Kim's equation: $\mathrm{GC}_{\text {average }}=332.14 \mathrm{scf} / \mathrm{ton}$. Using volumetric method to calculate the Gas in place, Gas in place $=4,610,647,000$ scf. Using $50 \%$ recovery factor and 18 holes drilled, Reserve gas $=41,495,823,000$ scf. From Eddy curve, Methane resources $=315 \mathrm{cf} /$ ton .

\section{H. Onyeama Graben}

Applying Kim's equation: $\mathrm{GC}_{\text {average }}=332.14 \mathrm{scf} / \mathrm{ton}$. Using volumetric method to calculate the Gas in place, Gas in place $=4,928,559,680 \mathrm{scf}$. Using $50 \%$ recovery factor and 23 core holes drilled, Reserve gas $=56,678,436,300$ scf. From Eddy curve, Methane resources $=312 \mathrm{cf} /$ ton.

\begin{tabular}{cccc} 
TABLE I: RESERVE ESTIMATE OF COAL FIELDS ACROSS NIGERIA \\
\hline Coal Field & $\begin{array}{c}\text { Gas } \\
\text { content } \\
\text { (scf/ton) }\end{array}$ & $\begin{array}{c}\text { Max } \\
\text { Methane } \\
\text { Resources } \\
\text { (scf/ton) }\end{array}$ & $\begin{array}{c}\text { Gas in place } \\
\text { (scf) }\end{array}$ \\
\hline Oba-Nnewi & 332.14 & 315 & $1,054,613,130$ \\
Inyi & 332.14 & 309 & $4,610,647,000$ \\
Ezimo & 332.14 & 315 & $983,864,271$ \\
Ogboyoga & 332.14 & 310 & $2,157,663,490$ \\
Okaba & 332.14 & 327 & $9,546,997,390$ \\
Orukpa & 332.14 & 306 & $1,853,214,000$ \\
Onyeama & 332.14 & 312 & $4,928,559,680$ \\
Okpara & 332.14 & 329 & $4,069,529,970$ \\
\hline \hline
\end{tabular}

The analysis assumed the Capital Expenditure (table 2) and Operating Expenditure (table 3) required to develop the eight Coal fields with reference to the Powder Basin River [4], [12].

TABLE 2: CAPITAL EXPENDITURE

\begin{tabular}{lcccc}
\hline Field & $\begin{array}{c}\text { No of } \\
\text { Wells }\end{array}$ & $\begin{array}{l}\text { Max Depth } \\
\text { of Seam }\end{array}$ & $\begin{array}{l}\text { Drilling and } \\
\text { Completion } \\
\text { Costs } \mathbf{( \$ )}\end{array}$ & $\begin{array}{c}\text { Total Capex } \\
\text { for the Field } \\
\mathbf{( \$ )}\end{array}$ \\
\hline Oba-Nnewi & 2 & 100 & 51,034 & 251,034 \\
Inyi & 18 & 295 & 203,790 & $6,300,000$ \\
Ezimo & 4 & 215 & 110,000 & $10,800,000$ \\
Oboyoga & 27 & 650 & 355,000 & $22,342,500$ \\
Okaba & 17 & 358 & 158,000 & $7,658,500$ \\
Orukpa & 11 & 261 & 155,000 & $3,723,500$ \\
Oyeama & 23 & 242 & 149,400 & $7,284,100$ \\
Okpara & 36 & 234 & 139,400 & $10,933,200$ \\
\hline \multicolumn{1}{c}{ Source: }
\end{tabular}

\begin{tabular}{|c|c|c|c|c|}
\hline Year & & 2016 & $2017-2018$ & 2019and above \\
\hline $\begin{array}{l}\text { Cost (\$) per } \\
\text { well }\end{array}$ & & 23,567 & 15,678 & 11,986 \\
\hline Field & $\begin{array}{l}\text { No of } \\
\text { wells }\end{array}$ & & & \\
\hline Oba-Nnewi & 2 & 47,134 & 31,356 & 23,972 \\
\hline Inyi & 18 & 424,206 & 282,204 & 215,749 \\
\hline Ezimo & 4 & 94,268 & 62,712 & 47,944 \\
\hline Oboyoga & 27 & 636,309 & 423,306 & 323,622 \\
\hline Okaba & 17 & 400,639 & 266,526 & 203,762 \\
\hline Orukpa & 11 & 259,237 & 172,458 & 131,846 \\
\hline Oyeama & 23 & 542,041 & 360,594 & 275,678 \\
\hline Okpara & 36 & 848,412 & 564,408 & 431,496 \\
\hline
\end{tabular}

Source: Global Mineral Limited (2008)

TABLE 3: OPERATING EXPENDITURE

\section{LNG AND PIPELINE PROJECTS FOR CBM}

Economic analysis of LNG and Pipeline projects for Coal Bed Methane transmission were comparatively examined. The study assumed physical, financial, technical and commercial conditions of LNG and Pipeline projects required to transmit 2,000,000,000,000scf of Methane gas reserve through a distance of $4000 \mathrm{~km}$ for a period of twenty years. 
As shown in table 4, the analysis estimated the total cost required for each case with reference to the World Bank report on LNG and Pipeline projects [4].

TABLE 4: COST OF LNG AND PIPELINE PROJECTS

\begin{tabular}{|c|c|c|c|}
\hline $\begin{array}{l}\text { Case of } \\
4000 \mathrm{~km}\end{array}$ & $\begin{array}{c}\text { CAPEX } \\
(\$)\end{array}$ & $\begin{array}{c}\text { OPEX } \\
(\$)\end{array}$ & $\begin{array}{l}\text { TOTAL COST } \\
(\$)\end{array}$ \\
\hline LNG & $1,752,000,000$ & $738,000,000$ & $2,490,000,000$ \\
\hline Pipelines & $1,775,000,000$ & $775,900,000$ & $2,550,900,000$ \\
\hline
\end{tabular}

\section{RESUltS}

The analysis used an excel spreadsheet to estimate the profitability of each Coal field. As shown in Table 5 to 7 , the study assumed three case scenarios. Table 5 displays the first case scenario that assumed Gas price (\$2), No tax (0), No Royalty (0) and Interest rate (10\%). The second case assumed Gas price (\$3), Tax (30\%), Royalty (5\%) and Interest rate $(15 \%)$ as shown in table 7 . The third scenario assumed Gas price (\$7), Tax (40\%), Royalty (10\%) and Interest rate $(20 \%)$ as shown in table 8.

TABLE 5: ANALYSIS FOR GAS PRICE (\$2), NO TAX (0), NO ROYALTY (0) AND INTEREST RATE (10\%)

\begin{tabular}{lcccc}
\hline Field & $\begin{array}{c}\text { Gas } \\
\text { Price } \\
\mathbf{( \$ )}\end{array}$ & $\begin{array}{c}\text { Net Present } \\
\text { Value }\end{array}$ & $\begin{array}{c}\text { Internal } \\
\text { Rate of } \\
\text { Return }\end{array}$ & $\begin{array}{c}\text { Discounted } \\
\text { Payback }\end{array}$ \\
\hline Oba-Nnewi & 2 & 640,773 & $48 \%$ & 2.08 \\
Inyi & 2 & $35,315,688$ & $93 \%$ & 1.07 \\
Ezimo & 2 & $-9,164,892$ & $-13 \%$ & 48.46 \\
Oboyoga & 2 & $5,325,613$ & $14 \%$ & 5.76 \\
Okaba & 2 & $75,682,353$ & $155 \%$ & 0.64 \\
Orukpa & 2 & $5,791,288$ & $34 \%$ & 2.81 \\
Oyeama & 2 & $49,728,579$ & $111 \%$ & 0.90 \\
Okpara & 2 & $62,075,666$ & $94 \%$ & 1.06 \\
\hline
\end{tabular}

TABLE 6: ANALYSIS FOR GAS PRICE (\$3), TAX (30\%), ROYALTY (5\%) AND INTEREST RATE (15\%)

\begin{tabular}{lcccc}
\hline $\begin{array}{c}\text { Coal Field } \\
\text { Areas }\end{array}$ & $\begin{array}{c}\text { Gas } \\
\text { price }\end{array}$ & $\begin{array}{c}\text { Net Present } \\
\text { Value }\end{array}$ & $\begin{array}{c}\text { Internal Rate } \\
\text { of Return }\end{array}$ & $\begin{array}{c}\text { Discounted } \\
\text { Payback }\end{array}$ \\
\hline \hline Oba-Nnewi & 3 & 519,576 & $54 \%$ & 1.84 \\
Inyi & 3 & $27,230,069$ & $97 \%$ & 1.03 \\
Ezimo & 3 & $-8,169,194$ & $-6 \%$ & 23.50 \\
Oboyoga & 3 & $2,431,540$ & $17 \%$ & 5.01 \\
Okaba & 3 & $58,455,667$ & $158 \%$ & 0.63 \\
Orukpa & 3 & $4,373,857$ & $38 \%$ & 2.55 \\
Oyeama & 3 & $38,454,347$ & $114 \%$ & 0.87 \\
Okpara & 3 & $47,982,104$ & $98 \%$ & 1.02 \\
\hline
\end{tabular}

TABLE 7: GAS PRICE (\$7), TAX (40\%), ROYALTY (10\%) AND INTEREST

\begin{tabular}{lcccc} 
Field & $\begin{array}{c}\text { Gas } \\
\text { Price } \\
\mathbf{( \$ )}\end{array}$ & $\begin{array}{c}\text { Net Present } \\
\text { Value }\end{array}$ & $\begin{array}{c}\text { Internal } \\
\text { Rate of } \\
\text { Return }\end{array}$ & $\begin{array}{c}\text { Discounted } \\
\text { Payback }\end{array}$ \\
\hline Oba-Nnewi & 7 & $1,015,394$ & $113 \%$ & 0.88 \\
Inyi & 7 & $45,647,476$ & $187 \%$ & 0.53 \\
Ezimo & 7 & $-7,160,256$ & $1 \%$ & 13.46 \\
Oboyoga & 7 & $15,750,192$ & $37 \%$ & 2.61 \\
Okaba & 7 & $94,117,778$ & $308 \%$ & 0.32 \\
Orukpa & 7 & $9,029,888$ & $77 \%$ & 1.29 \\
Oyeama & 7 & $63,572,357$ & $222 \%$ & 0.45 \\
Okpara & 7 & $80,566,496$ & $190 \%$ & 0.52 \\
\hline
\end{tabular}

The Excel spread sheet result of the LNG and Pipeline projects analysis are tabulated in table 9.

\begin{tabular}{cccc}
\multicolumn{4}{c}{ TABLE 8: ANALYSIS OF LNG AND PIPELINE PROJECTS. } \\
\hline $\begin{array}{c}\text { Case of } \\
\text { 4000km }\end{array}$ & $\begin{array}{c}\text { Net Present } \\
\text { Value }\end{array}$ & $\begin{array}{c}\text { Internal Rate } \\
\text { of Return }\end{array}$ & $\begin{array}{c}\text { Discounted } \\
\text { Payback }\end{array}$ \\
\hline LNG & $61,311,078$ & $11 \%$ & 7.62 \\
Pipelines & $30,226,608$ & $10 \%$ & 7.77 \\
\hline \hline
\end{tabular}

\section{DISCUSSION}

From table 5 to 7 , it can be observed that Oba Nnewi, Inyi, Ogboyoga, Okaba, Orukpa, Onyeama and Okpara Coal Fields are economically viable to be produced to add to the natural gas reserves of Nigeria at present.

From analysis of the sensitivity, it is observed that the Taxes, Royalty CAPEX, OPEX, Production rate and the Gas price have significant effect on the Net present value (NPV), Internal rate of returns (IRR) and the Discounted Payback period thus the economic viability of the project. Change in the Interest rate has significant effect on the Net Present Value but little or no effect on the Internal rate of return and the Discounted payback period.

Increase in the ultimate reserves, production rate and the price of gas will make the production of coal bed methane more profitable in Nigeria. The ultimate reserves can be increase, if potential areas of CBM are exploited.

Decrease in CAPEX and OPEX will lead to an increase in the NPV, IRR, Discounted Payback and thus an increase in the profitability of CBM production. To reduce the capital cost, technology that is not expensive and environmentally friendly should be employed.

Decrease in Taxes and Royalties will lead to an increase NPV and IRR results. This will lead to an early discounted payback period of the investment. Therefore, potential investors can be encouraged, if incentives are provided in the country's fiscal regime for coal mining exploitations. Decrease in the Interest rate will result to an increase NPV.

From table 8, the LNG project is cost effective than the Pipeline project. The study shows how the difference in distance will affect the comparative costs of LNG and Pipeline projects. From figure 1, the cost of pipeline quickly increases with distance since the analysis assumed that the pipeline cost calculation is simply based on cost per length. The whole cost depends on the length here, regardless of how real this is or not.

In the case of LNG, much of the investment is made in the liquefaction and re-gasification which are not distance dependent. The part of shipping in the whole LNG chain is surely distance dependent, but its share in the total cost of the chain is rather small.

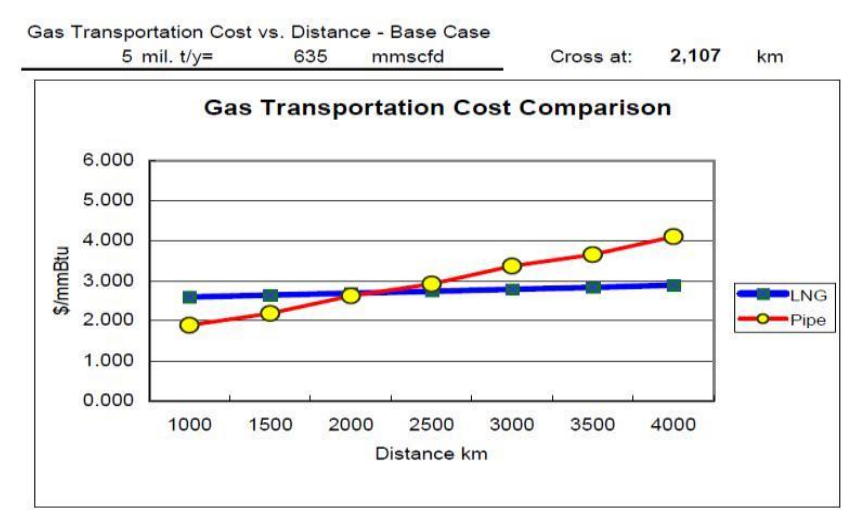

Fig. 1. Cost changes with distance.

The study used the "cross distance" shown in figure 1 to be the transportation distance above which LNG is economically more advantageous. From figure 1, the cross distance is $2107 \mathrm{~km}$. The analysis describes the following factors affecting the cross distance. 
(1) Effect of Potential Pipeline Cost Cut: The result shows an increase in the cross distance. When the Pipeline is installed at a cost lower than US $\$ 35 / \mathrm{m} / \mathrm{inch}$, it is more advantageous than LNG.

(2) Project Size and Choice of Parallel Pipes: Depending on the size of the project, multiple pipeline projects are cost effective than single pipeline projects.

(3) Effect of the Cost of Liquefaction Plant and LNG Ships: The result show a reduction in the cross distance which means that for a further cost cut of an LNG liquefaction plant and LNG ship, the LNG project is economically cheaper than the pipeline project.

(4) Effect of Discount Rate: An increase in the discount rate show a decrease in the cross distance and makes LNG project economically preferable. The pipeline project can be considered at a low discount rate.

\section{CONCLUSION}

1) At present the eight Coal fields can increase CBM production in Nigeria.

2) Sensitivity analysis shows that methane gas price increases periodically. Hence, the development of Coal Bed Methane can be economically viable to investors.

3) Reduction in CAPEX, OPEX, Royalty and Taxes can considerably increase economic development of CBM.

4) When there are many markets scattered on the transmission route, the pipeline may be a better selection for supplying broader markets.

5) Gas transmitted through LNG projects is stored properly because it is initially liquefied.

6) Parallel pipelines connected in the form of loop are cost effective than single pipeline projects.

7) The actual cost of upstream exploration of CBM field and downstream transportation through LNG and Pipeline varies from project to project.

8) LNG has benefit from storage function and access to diversified natural gas supply sources.

\section{ACKNOWLEDGEMENT}

The Authors will like to express our sincere gratitude to Prof Iyagba Tamuno Elijah for his guidance and encouragement. We also want to thank the Laboratory Assistants in the Federal Polytechnic of Oil and Gas Bonny, for their technical support.

\section{REFERENCES}

[1] R.R.D Dhir and J.M Mavor. "Economics and Reserves Estimation of Coal-bed Methane Reservoirs". Oil \& Gas J. London, Chapter 8, No. 52. 2016.

[2] W.P Diamond and J.R Levine. "Direct Method Determination of the Gas Content of Coal, Procedures and Results". Report of Investigations 8515, U.S. Department of the Interior, Bureau of Mines, Washington, D.C. 2015.

[3] G.E Eddy, C.T Rightmire, and C.W Byren. "Relationship of Methane Content of Coal Rank and Depth" Theoretical vs. Observed: Society of Petroleum Engineers, Department of interior, Proceedings, Unconventional Gas Recovery Symposium, Pittsburg, Pennsylvania, SPEDOE 10800, pp 117-122. 2016.

[4] Global Mineral Limited. Proceedings of First Mineral Conference Workshop, Ministry of Solid Minerals Development, Federal Republic of Nigeria, Abuja, pp 1-50, 2008.

[5] C.B Gregory and A.K Vello. "Economics of Powder River Basin Coal-bed Methane Development". Prepared for the U.S. Department of Energy, Washington, Chapter 3, 2015.

[6] J. Karweil. "Advances in Geochemistry". Oxford Pergamon Press, Pp59-84, 2016.

[7] A.G Kim. "Estimating Methane Content of Bituminous Coalbeds from Adsorption Data" U.S. Bureau of mine, Report of investigations $8245,1977$.

[8] S.W Lambert. "Comparison of Open Hole, Slotting and Perforating Completion Methods for Multiseam Coalbed Gas Wells," Coalbed Methane Symposium, Tuscaloosa, Alabama, pp 262. 2017.

[9] S.M Lloyd and R.Senjen. "Hydraulic Fracturing in Coal Seam Gas Mining, the risks to our Health, Communities, Environment and Climate". Briefing paper, National Toxics Network, 2015.

[10] A.D McKinney. "Advanced Reservoir Engineering" Gulf Professional Publishing, New York, No. 4, pp680-690, 2015.

[11] M.C Mpadi. "The Impact of the Nigerian Oil and Gas on her Coal Industry". Proceedings of International Conference on Energy. Port Harcourt, Nigeria. 2014.

[12] Nigerian Coal Corporation. Summary Report on Privatization of Coal Fields across Nigeria. Enugu, 2004.

[13] W. Nugroho and G. Arsegianto. "Economics of Coal-Bed Methane Field Development". A Case Study of Jatibarang Field, SPE Paper 225311, pp 21, 2015.

[14] G.W Reid, B.F Towler and H.I Harris. "Simulation and Economics of Coal Bed Methane Production in Powder River Basin". SPE Paper No 24360. Presented at the 1992 SPE Rocky Mountain Regional Meeting, Casper, No. 13, 425-432, 1992.

[15] D.A Simpson, J.F Lea and J.C Cox. "Coal Bed Methane Production". SPE Paper 80900, Presented at SPE Production and Operation Symposium held at Oklahoma City, Oklahoma U.S.A, 2016.

[16] U.Z.S Youngson and A. Michniewiez,. "Coal-Bed Methane Companies Overview”. Sector Report, Manchester, Chapter 6, pp 18, 2017.

[17] World Bank Report. Federal Government of Nigeria Economic Reform Governance Project, Lagos, Volume1. pp 12-65, 1994.

[18] M.D Zuber and D.E Wicks. "Methane from Coal Deposits Technical Evaluation and Data Base," Quarterly Review of Methane from Coal Seams Technology No.41, 2017. 